\title{
Application of Didactic Methods in Planting Values of Culture Through Maligya Ceremony at Hindu Communities
}

\section{Gusti Ayu Santipatni R ${ }^{1 *}$}

${ }^{1}$ Sekolah Tinggi Agama Hindu Negeri Gde Pudja Mataram, Lombok Barat, Indonesia

\section{A R T I CLE INFO}

Article history:

Received January 21, 2021

Revised January 25, 2021

Accepted April 24, 2021

Available online May 25, 2021

Kata Kunci :

Penanaman Nilai-Nilai, Praktik

Budaya, Upacara Maligya

Keywords:

Cultivation Of Values, Cultural Practices, Maligya Ceremony

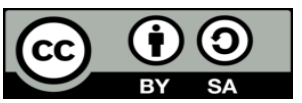

This is an open access article under the CC BY-SA license.

Copyright $(2021$ by Author. Published by Universitas Pendidikan Ganesha

\begin{abstract}
A B S T R A K
Upacara maligya merupakan pelaksanaan agama Hindu yang melibatkan praktik budaya Bali di Lombok. Penelitian ini bertujuan untuk melakukan kajian terhadap penerapan metode didaktik dalam penanaman nilai-nilai budaya melalui upacara maligya di lokasi penelitian. Fokus penelitian ini pada penerapan metode didaktik dalam menanamkan nilai-nilai budaya melalui upacara maligya. Metode penelitian ini adalah kualitatif interpretatif dengan pendekatan studi kasus. Hasil analisis data menemukan tiga temuan baru. Pertama, dimensi pengenalan nilai-nilai budaya dalam praktik beragama sebagai aspek kognitif dalam pelaksanaan upacara maligya melibatkan aspek kesadaran untuk belajar seumur hidup. Kedua, dimensi penghayatan nilai-nilai budaya dalam upacara maligya sebagai implementasi aspek afektif yang berkaitan dengan dengan kesadaran untuk menghargai nilai-nilai budaya warisan leluhur. Ketiga, dimensi pengamalan nilai-nilai budaya dalam praktik upacara maligya berkaitan dengan terwujudnya rasa bhakti kehadapan leluhur dan pelestarian nilai-nilai budaya warisan leluhur sebagai wahana meningkatkan kualitas hidup pada masyarakat Hindu yang melaksanakannya. Berdasarkan hasil penelitian ini dapat disimpulkan bahwa metode didaktik merupakan strategi yang efektif dalam menanamkan nilai-nilai budaya dalam pelaksanaan agama Hindu melalui upacara maligya.
\end{abstract}

\begin{abstract}
A B S T R A C T
The maligya ceremony is an implementation of Hinduism that involves Balinese cultural practices in Lombok. This study aims to study the application of didactic methods in cultivating cultural values through the maligya ceremony at the research location. The focus of this research is on the application of didactic methods in instilling cultural values through the maligya ceremony. This research method is qualitative interpretive with a case study approach. The results of the data analysis found three new findings. First, the dimension of introducing cultural values in religious practice as a cognitive aspect in the implementation of the maligya ceremony involves an aspect of awareness for lifelong learning. Second, the dimensions of the appreciation of cultural values in the maligya ceremony as the implementation of the affective aspects related to the awareness to respect the cultural values of ancestral heritage. Third, the dimension of practicing cultural values in the practice of the maligya ceremony is related to the realization of a sense of devotion before the ancestors and the preservation of cultural values as a means of improving the quality of life of the Hindu community who performs it. Based on the results of this study, it can be concluded that the didactic method is an effective strategy in instilling cultural values in the implementation of Hinduism through the maligya ceremony.
\end{abstract}

\section{INTRODUCTION}

The development of science and technology has a very significant impact on how to live the teachings of Hinduism in the lives of people. The implementation of the teachings of Hinduism is based on three basic frameworks, namely tattwa, susila, and acara (Suryawan \& Gata, 2020; Titib M., 2000). Tattwa in the implementation of Hinduism is sraddha (belief) which has a foundation in living the teachings of religion in daily life. Susila is ethic aspect which is actualized in the implementation of Hinduism. The acara is an aspect that is related to the procedures for living the religious teaching in accordance with habits that have truth values in living the religious teachings. The aspect of acara was expressed in several territories with the yajña ceremony. The three aspects within the basic framework of Hinduism are interrelated with one another (Darmawan, 2020; Pitriani, 2020).

The implementation of Hinduism in daily life is more expressed in aspects of religious events. This aspect of religious events is implemented in the form of yajña ceremonies as a way of living Hinduism which is weighted on the aspects of splendor and communality (Renawati, 2019; Wiriawan, 2021). The practice of Hindu religious ceremonies which are actualized as living the teachings of Hinduism are highly conditioned by the space and time in which the teachings of Hinduism are implemented. The 
implementation of religious teaching based on space and time is often referred to as desa, kala, patra. Desa means region, kala is a time, namely that concerns the style of ala ayuning desawa (good and bad time of the implementation of Hindu religious ceremonies). Patra is a socioeconomic state, situation conditions, and forms of implementation of Hindu religious ceremonies. With regard to that in the implementation of Hinduism called yajña there the three level categories are known as nista (simple), madya (intermediate), utama (ultimate) (Putra, 1988; Wiriawan, 2021). The implementation of the yajña ceremony carried out by Hindus is a continuation of the form of Vedic worship which brings together the macrocosm and the microcosm, between ätman and Brahman, or between man and his Lord. Evaluation and development of the concept of yajña can be seen in the books of Sruti and Smerti, as well as the theoretical and practical aspects contained in us Bhagawadgita. In the book illustrated the philosophy of ethical life that collectively can lead to the achievement of abhudaya (social welfare) and individually can direct the achievement of realization selves. The concept of yajña in its development has been mixed with puja rituals and the four yoga systems, namely karma, bhakti, dyana, and jnana. This phenomenon is a development of the concept of yajña which is more established (Suamba, 1996). Self-realization is related to improving the quality of self through religious practices based on the belief system adopted by Hindus.

In the life of the Hindu community in Cakranegara tri rna is realized in the form of the implementation of the panca yajñas (five kinds of holy scarifice). Dewa rna is paid by carrying out dewa yajña and bhuta yajña, rsi rna is paid by implementing rsi yajña, and pitra rna is paid by implementing pitra yajña and manusa yajña. Dewa yajña is a sacred sacrifice performed sincerely before Ida Sang Hyang Widhi Wasa (God Almighty) along with all his manifestations. Rsi yajña is a sincere sacrifice to the saints who have contributed to developing Vedic teachings or science to help human life. Pitra yajña is a sincere sacrifice to both parents or ancestors who have died. Manusa yajña is a sincere sacrifice to the human kind. Bhuta yajña is a sacred sacrifice to bhutas (natural forces that have helped human life). With regard to the implementation of the maligya ceremony carried out by the Hindu community in Cakranegara is the implementation of the pitra yajña ceremony. The pitra yajña ceremony is a way to pay debts to the ancestors (I. B. P. Sudarsana, 2002; Wiana, 1998). The word pitra also means ancestor. Ancestors are counted from fathers and mothers and above who have a very large role and determine the lives of future generations. Pitra yajña as a form of conduct of devotional service to the ancestors has a positive value so it needs to be maintained and developed.

The implementation of the pitra yajña ceremony has not been considered complete if it has not carried out the stage of "ngelingggihan dewa pitara", namely placing the ancestral spirits that have been sacred in a place equivalent to the dewa pitara (gods). The second stage is called mamukur. The term mukur is derived from the word bukur is an acronym from the word "bhu" which means nature and the word "ur" (derived from the word urdhah) which means above. The word bukur is interpreted as going to the upper realm or to the realm of swah loka (the realm of gods). This ceremony is also called the maligya ceremony. Maligya ceremony is a form of actualization of the implementation of religious ceremonies by integrating cultural values, customs, which are in accordance with the desa, kala, and patra. In the Hindu tradition in Bali and in Lombok that can be worshiped is an ancestor who has reached the stages of the dewa pitara or also called has reached the stage of "sidha dewata". This is described in the manuscript of" Pūrwa Bumi Kamulan" and several other manuscripts. The dewa pitara is an ancestor whose purity is believed to be on par with the gods. According to the teachings of Hindu devotional devotion to parents or ancestors is not enough when he was still alive, but also after he left this virtual world (I. B. P. Sudarsana, 2002; Wiana, 1998). Based on this concept the implementation of the maligya ceremony has a literary foundation in the form of the manuscript "Purwa Bumi Kamulan" which in essence emphasizes the importance of carrying out the maligya ceremony to improve the status of the a tma of ancestors who have died so that they become dewa pitara (gods and goddess).

The implementation of the maligya ceremony in the life of the Hindu community in Lombok needs to be done in order to pay off debts, especially service debts provided by the ancestors so as to realize the sanctity of the ancestors and also the welfare of their offspring. In connection with that, in the life of the Hindu community in Cakranegara the Maligya ceremony was held in an open space near a public temple. This ceremony is a form of actualizing the implementation of a new categorized ceremony. The Hindu community in Lombok in its historical range has not yet performed a maligya ceremony, as has been carried out by the Hindu community in Bali who have traditionally performed the maligya ceremony after carrying out the ngaben ceremony. Not all maligya ceremonies are held in Hindu society in Lombok. This is due to the continuing factor of Hindu traditions carried out by their predecessors who did not perform the maligya ceremony after the ngaben ceremony (I. K. Sudarsana, 2017; Yanti, 2017). The influence of the implementation of religion on Balinese society lately led to a number of adaptations, so that the Hindu community in Lombok also performed a maligya ceremony. In this connection, it is necessary to understand Hindus about the importance of the maligya ceremony as a continuation of the ngaben 
ceremony to improve the status of the ätman of their ancestors. The effort to build awareness is done by instilling cultural values in religious practices through the direct involvement of Hindus, especially the younger generation in the implementation of the maligya ceremony. In instilling cultural values is related to internalization. Internalization is a process of instilling values about culture (Zafi, 2018). In planting and growing these values is carried out through various didactic methods of education and teaching. In synergy with that, the benefits of internalization are for development, improvement and screening in cultural terms (Satori \& Widiastuti, 2018).

In connection with the above conditions, it is necessary to conduct a study related to the implementation of the maligya ceremony of the Hindu community in Cakranegara as a vehicle to educate young Hindu generations to understand the importance of building devotion to their ancestors until he is an attma siddha dewata. This research is more focused on the study of three aspects concerning the inculcation of cultural education values in the implementation of religion. First, the application of the didactic method in planting cultural values as a cognitive aspect contained in the implementation of the maligya ceremony in the Hindu community in Cakranegara. Second, identifying the application of didactic methods in planting of cultural values as an affective aspect in the implementation of the maligya ceremony in the Hindu community in Cakranegara. Third, find the application of didactic methods in planting cultural values as a conative dimension in the implementation of the maligya ceremony in the Hindu community in Cakranegara. The results of this study are expected to contribute, in particular to increasing the awareness of the Hindu community about the application of the didactic model in the inculcation of cultural values contained in the implementation of the maligya ceremony as a noble legacy of Hindu religious practices in improving the quality of life.

\section{METHODS}

The research design in order to analyze the problems relating to the "Application of the Didactic Method in Planting Cultural Values through the Maligya Ceremony at Hindu Community in Cakranegara" is an investigation structure that is structured to obtain an overview related to the research conducted. The design is a comprehensive scheme that includes research programs carried out. The research design was also arranged based on the results of initial observations and served to provide a general picture of the activities carried out in the field. This research uses qualitative research that has flexible characteristics so that it has the opportunity to develop and change according to the situation and conditions that occur in the field. Based on its characteristics as a qualitative study, the stability and clarity of steps in his research will be known after the research is completed (Arikunto, 2002; Muhajir, 1990; Satori et al., 2010). The selection of data in qualitative research is carried out by the researcher himself when conducting data analysis. In synergy with that, qualitative research is also based on the nature of research that is always oriented to symptoms that are genuine and natural (Miles et al., 2014; Sugiyono, 2012).

Types of data in a study can be divided into two, namely qualitative data is data in the form of words or sentences. While Quantitative Data is data in the form of numbers. With regard to this research is qualitative research, the type of data needed is in accordance with the characteristics of this research qualitative research, the data needed in the form of qualitative data as the main data and quantitative data as supporting data. Qualitative data is data in the form of expressions, words, ideas or ideas, opinions, and notes relating to the problem under study. Primary Data Sources in this study are data obtained from interviews with community leaders, religious leaders, and government elements who control the issues to be investigated, namely: the implementation of the maligya ceremony. Secondary Data Sources are data that is complementary or comparative to Primary Data sources. In this study the source of secondary data is the study of various sources of library (library research) in the form of: documents, books (literature) reports of research results, papers, articles relating to the subject matter under study. Secondary data sources can also be obtained from direct observation (observation) of the research object (field research).

Informants in this study are people who know and are able to provide the widest possible information about the problem to be studied. Based on this, the selection and determination of informants is based on the need for research data obtained in the field. Based on these meanings, the active participation of informants to provide accurate and complete data about what the researcher wants is very important. Therefore, the accuracy of informant determination techniques is needed in order to obtain data whose validity can be scientifically justified. Based on the above considerations, in determining the informant in accordance with the type of this research is qualitative research, then the determination of the information using the purposive technique is the determination or determination of the informant with special characteristics in accordance with the research objectives so that it is expected to answer the research problem. Linked to the meaning, the determination of informants in this study are 
religious leaders, community leaders, cultural figures and traditional leaders who are considered capable of providing the data needed in this study.

Data availability and validity are important in a study. Based on this understanding, the data collection techniques can really be chosen and prepared carefully. The data collection techniques that the author uses in this study are: (1) Observation Techniques, (2) Interview Techniques, (3) Document Studies, and Literature Studies. Observation techniques are daily activities using eye senses (to see), ears (to hear), nose (to smell) as aids in making observations, so observation is referred to as a way of collecting data using the ability senses to get data in the field (Bungin, 2001). The observation technique is a conscious effort to collect data that is carried out systematically with standard procedures, that is, recording data in observations is not just recording, but also conducting assessments on a multilevel scale. Documents relating to this research are books, photographs, pictures, and films / videos related to problems that can support the completeness of the required data. To complete the data in this study, researchers examined several references in the form of books books, e-books and scientific works such as journals, research results that have been related to the problem under study. Linked to the research to be used, the literature study used is focused on supporting sources related to the implementation of the didactic method in embedding cultural values at the maligya ceremony.

Data analysis is the process of systematically searching and compiling data obtained from interviews, field notes and other materials so that they are easily understood, and their findings can be shared with others. Analysis of data or can also be called the processing and interpretation of data as a series of review, systematization and verification of data so that a phenomenon has social, academic and scientific value (Suprayogo \& Tabroni, 2001). All of that is a unity that has been intertwined at the time before, during and after data collection in a parallel format to build general insight called analysis. Qualitative data analysis is an effort made by working with data, organizing data, sorting out into manageable units, synthesizing them, searching and finding patterns, finding what is important to learn, and decide what can be told to others (Moleong, 2012). Given that the data obtained in the form of words, sentences, paragraphs that are stated in narrative form are descriptive, then the data analysis used is descriptive-interpretative techniques.

Data analysis is done by organizing data, describing it into units, synthesizing, arranging into patterns, choosing what is important and what will be studied, and making conclusions that can be shared with others. After all the necessary data is collected, then data processing is needed by selecting, classifying and codifying the data. The next step is data analysis activities. Because this research is qualitative, it means that the data presented is in the form of sentences or words in sentence form and not a series of words. Then the data analysis used is interpretive descriptive analysis, namely by conducting a study of an objective phenomenon (in accordance with library and field data) which is the object of research. Descriptions are balanced with interpretations. An endless description will be mixed up on its own. The purpose of analysis is to organize descriptions by making them controllable. The description is balanced by analysis and delivery into interpretation (Emzir, 2011).

\section{RESULT AND DISCUSSION}

\section{Results}

Based on the results of this study, three important dimensions were found relating to the application of didactic methods in planting of cultural values through Maligya ceremonies in the Hindu community in Cakranegara, namely the dimensions of the introduction of cultural values in maligya ceremonies, the dimensions of appreciation of cultural values in maligya ceremonies, and the dimensions of the practice of values in the maligya ceremony which are used as a vehicle to instill the noble cultural values inherited by the predecessors. These three aspects are described in the following sections.

\section{Dimensions of Introduction of Cultural Values in the Implementation of the Maligya Ceremony}

Communities in Indonesia have a variety of local wisdom that grows from a number of regions. Local wisdom is used as a vehicle to overcome the problems faced in their lives, both individually and in groups. Local wisdom has been built by their predecessors and is still used today in a number of community groups. Local wisdom in various regions in Indonesia is evidence of Indonesia's cultural wealth (Fuad et al., 2020). In connection with the existence of local wisdom which is still preserved by the Hindu community in the form of ritual traditions in the implementation of Hinduism. The ritual ceremony is used to be performed by Hindi people in Bali. In recent years the Maligya ceremony has also been carried out by the Hindu community in Lombok, especially in the Cakranegara region. The implementation of the maligya ceremony in Cakranegara was categorized as a new ritual in living up to the teachings of Hinduism. Based on historical data conveyed by a number of Hindu community informants in Lombok in 
general, rarely performed a maligya ceremony. The ceremony was held in Bali, as told by Ida Ayu Oka Putra (an informant) that the maligya ceremony was indeed in the life of the Hindu community in Bali accustomed to be carried out. The implementation of the maligya ceremony in Bali used priests as the leader of more than one ceremony, some even used priests totaling five or six or it could be more than that.

In the maligya ceremony carried out by the Hindu community in Lombok, it seems to have followed the maligya ceremony performed by the Balinese people. The maligya ceremony in Cakranegara was a continuation of the pitra yajña (ngaben ceremony) ceremony as a ceremony aimed at purifying ancestral spirits so that it could escalate into atma siddha dewata. The purification of ancestral spirits became the attma siddha dewata conducted by the Hindu community in Cakranegara in essence to release the bonds that surround the body of antah karana in order to be able to go to the place according to karma (deed) while living. According to Hindu teachings that the àtma of a person who has passed away will continue to experience birth, life and death which is called incarnation. The process of reincarnation aims to achieve liberation (moksa) and if this goal has been reached then the spirit or a $\bar{t}$ tma stops experiencing the process of birth, life, and death (Gentorang, 2016). Moksa is the ultimate goal of the journey of human life who embraces Hinduism (Putra, 1982; Wiana, 2004).

The implementation of the maligya ceremony in the life of the Hindu community in Cakranegara as a form of devotion to the pratisentana to their ancestors. There is a rite of ceremony called ngeliwet which means the pratisentana (descendants) of people who died doing prostrations of devotion to their ancestors. Meaning as sign language from relatives to ask the presence of Ida Sang Hyang Widhi Wasa so that the family members who carry out the ceremony are blessed with a good path. Related to this, the ngeliwet ceremony process contains the teachings that pratisentana (descendants) should carry out devotion to the ancestors who has provided care services from the womb to adulthood. The maligya ceremony in its implementation there are relatively long sequences as a ritual process, each of which has meaning. The stages carried out at the maligya ceremony if followed from the beginning to the end of the ceremony can provide an introduction to these stages which can then be internalized in Hindus to be continued in the implementation of the ceremony in the next period. Introduction to the implementation of the ceremony is actually a way to introduce cultural practices in carrying out religious teachings. In this regard, the teachings of Hinduism are the spirit that animates Hindu religious practices that are actualized in daily life. Cultural practices that are implemented in the maligya ceremony are containers used to implement Hinduism. The introduction of cultural identity in the practice of maligya ceremonies is a strategy to instill cultural values in living the teachings of Hinduism to followers of Hindu religion, especially among the younger generation or the next generation. The introduction of these cultural values in relation to education is part of the cognitive aspects, self-recognition is part of the cognitive aspects (Tantra, 2015). This cognitive aspect is inherent in the didactic method, which is a method used to pass on the knowledge, skills and attitudes imbued by the teachings of Hinduism which are implemented in the practice of the maligya ceremony.

\section{Dimensions of Understanding Cultural Values in the Maligya Ceremony}

The Hindu community in Cakranegara that carries out the maligya ceremony basically has an appreciation of the religious values that are implemented in cultural practices. The appreciation of the implementation of the maligya ceremony is implemented in resting faith in the implementation of the ceremony as a vehicle to realize a sense of devotion to the ancestors who are already in the afterlife. The expression of devotion that is realized through the implementation of the ceremony is based on sincerity. The basis of sincerity that grows in the Hindu community carrying out the maligya ceremony is also manifested in actions that consciously carry out the ceremony without calculating the profit and loss, both materially and nonmaterially. Sincerity in the implementation of the maligya ceremony is indicated through sacrifices made in the form of material so that the implementation of the ceremony can run smoothly. Sincerity in the nonmaterial aspects is indicated by the sacrifice of time and energy.

Related to the implementation of the maligya ceremony which requires a relatively large special place is also one of the sacrifices made as a manifestation of devotion by the Hindu community who became yajamana, namely the person carrying out the ceremony. Based on an expression from Ida Pedanda Gede Nyoman Keniten (an informant) revealed that in carrying out the ceremony maligya must be held outside the yard of the house. This is because the implementation of the ceremony requires a relatively large place to make ceremonial facilities, such as bale peyadnyan, bale payogan, sanggar tawang, sanggar surya, bale pamutruan, and bale pengliwetan. After these places are determined next is a renewal ceremony using caru panca sata. The renewal ceremony is intended to purify or clean the place. Based on the phrase conveyed above, in carrying out the maligya ceremony a relatively large space is needed so that the ceremony can run smoothly. The need for a large place is part of the smooth implementation of the 
ceremonial process. Based on the results of observations in the field it was found that to obtain a relatively large area of land in the territory of Cakranegara was very difficult. Nevertheless, the Hindu community who carried out the maligya ceremony tried to get an adequate place so that the ceremony could run smoothly.

The Hindu community in Cakranegara who carried out the maligya ceremony sought to realize the ideals of providing relatively large land in order to carry out the ceremony. The efforts made to obtain land in the context of ceremonial activities are actually a form of devotion from pratisentana (descendants) to the ancestors given the ceremony. In connection with that those who carry out the maligya ceremony with purity of heart carry out the ceremony so that it can run smoothly. This is in line with the phrase that the implementation of the maligya ceremony is a work of hayu, which is a purity ceremony so that in the context of the implementation of the ceremony it must be based on purity (Purwita, 1997). Another form of sincerity in carrying out the maligya ceremony is to carry out the matur piuning ceremony. The ceremony was conducted at ten temples including, Lingsar Temple, Suranadi Temple, Narmada Temple, Gunung Pangsung Temple, Segara Temple, Batu Bolong Temple, Gunung Sari Temple, Gunung Baliku Temple, Sarasuta Temple, and Karang Jangkong Temple. In addition to the matur piuning ceremony held at the temple, they also performed at their respective celebrations. In carrying out the matur piuning ceremony, the piuning uses the means of upakara, in the form of offering one pajeg (apajeg). The matur piuning ceremony is intended as a symbol of announcement to Ida Bhatara-Bhatari in the temple and also in Kawitan Temple. In addition to the implementation of the matur piuning ceremony, as mentioned above there are a number of series of ceremonies performed in the implementation of the maligya ceremony. The series of ceremonies is basically showing the devotion to the ancestors given the ceremony. Hindus who carry out ceremonies are not based on feelings of compulsion, but instead they carry out these ceremonies based on sincerity. The basis of the implementation of the ceremony, in the form of sincerity is very important because it leads to the purpose of the ceremony. This is consistent with what the Bhagavad Gìtā says, as in the following passage.

\section{Patram pușpam் phalam toyam \\ Yo me bhaktyā prayacchati, \\ Tad aham bhakty-upahrtam \\ Aśnāmi prayatātmanaḥ.}

\section{Bhagavad Gītā IX-26}

Meaning: Whoever bows worship to me offers a leaf, a flower, a fruit, a sip of water, I accept it as a devotional offering from a pure hearted person. The implementation of the maligya ceremony which is based on sincerity in addition to aiming to make the holy ancestors called attma sidha dewata also believed to have an influence on their descendants. The descendants who carry out the maligya ceremony get good results from the karma (deed) they do. In this regard, the good karma of the sentana (offspring) to the ancestors is the karma of someone called a suputra child. The birth of a child who is suputra and performs acts of virtue, then the child exerts influence, as a fusion of the sins of ten levels of his ancestors, ten levels of his offspring, and he himself is among the twenty-first. In the process of the maligya ceremony there is also a so-called pengajuman ceremony. This ceremony is carried out by all relatives as a form of devotion to the ancestors. The meaning of the ceremonial ceremony or also often called the ngajum sekah ceremony is to ask that the spirits of the deceased deign to be present and to place at the puspa sarira. Pusra Sarira ceremony is a symbol of the spirit of the people being celebrated, where the name is written in a pipil. The ceremonial ceremony that relatives had an active role in the family. the ceremony is led by a priest whose authority gives instructions, because the dissolution of the sins of his spirit can only be dissolved by his own karma or the influence of good karma from his sentana (I. B. P. Sudarsana, 2002).

Based on the description above in the implementation of the maligya ceremony carried out by the Hindu community in Cakranegara there is an affective education dimension involved in it. The dimensions of affective education can be seen in the procedures for living up to the implementation of the maligya ceremony by involving aspects of feeling. In this context the Hindu community who carried out the ceremony with full sincerity to perform holy sacrifices, both material and non-material, in order to realize the sense of devotion to the ancestors they seek. Sacred sacrifices made in material form are indicated by their sincerity in making sacred sacrifices through their possessions. Sacred sacrifice in the nonmaterial aspect is indicated by the sacrifice of time and energy willingly dedicated to the smooth implementation of the maligya ceremony. In connection with that affective values through the outpouring of feelings is an awareness to carry out the obligation as pratisentana (offspring) of the ancestors who are celebrated. Based on the description above in the implementation of the maligya ceremony there is a very important aspect contained in it, namely the appreciation of cultural values in the implementation of Hinduism. The 
appreciation of these cultural values related to the educational aspect is a didactic method in order to provide knowledge, skills and attitudes to Hindus to carry out religious teachings through the practice of maligya ceremonies. Synergizing with it in the aspect of appreciation of cultural values in the implementation of the maligya ceremony is an affective dimension. This is in line with the idea that the appreciation of values is part of the affective dimension. This is a practice of character that is carried out in social life (Tantra, 2015).

\section{Dimensions of Practicing Cultural Values in the Implementation of the Maligya Ceremony}

The Hindu community in Cakranegara carrying out the maligya ceremony is a new type of ceremony because before their predecessors had never carried out the ceremony. This is an implementation of a ceremony whose character is pioneering the influence of the Hindu community in Bali. Although it is a new ceremony, the Hindus who carry out the ceremony do it very seriously because it is believed to be the embodiment of the devotees of the pratisentana (descendants) before the ancestors who have headed to the realm of the noetic. In this regard, Ida Bagus Putu Buana (an informant) revealed that Hindus who carry out the maligya ceremony show devotion to the ancestors who have died with full sincerity. In the performance of the maligya ceremony an ox is used as a symbol to show the path to the atma. This is based on the belief that an ox is a vehicle of "Bhatara Siwa" so it is believed that it will give directions to where "Bhatara Siwa" is. The symbol used in the implementation of the maligya ceremony in this context as a vehicle (vehicle) to deliver the ätma to Bhatara Siwa in hopes of being united with him.

The manifestation of devotion that is expressed through the maligya ceremony is a form of awareness of pratisentana (descendants) to perform yajñas (holy sacrifices) before the ancestors who have died so that their spirits get a place to the place of the gods. This embodiment of devotion is a service that has been done by the ancestors who have cared for and educated their descendants with compassion. A son born from an honorable marriage (brahma wiwaha) if those sons do useful things, they will be able to atone for the sins of ten levels of their ancestors and ten levels of their offspring (Wiana, 2004). This means that there is a link between ancestors and their offspring. The offspring are obliged to serve their ancestors, while the ancestors must pay affection to their offspring. If the offspring serve the ancestors, then the service can reduce the sins of the ancestors. Likewise, on the contrary, if the ancestors pour out their affection by willingly sacrificing their offspring, then this action will also be able to atone for the sins of their offspring.

The practice of cultural values in the maligya ceremony is corroborated by the teachings of the book Rgveda X. 15.1 there is mentioned an offering to ask for ancestral grace. On the contrary in the same Rg Veda book in Mantra number two it is also stated with devotion to his descendants, then the ancestors will get a proper place in the noetic realm. The revered ancestor is an ancestor who has been purified through a procession of purification ceremony. The procession of purification of ancestral spirits began when he left his container body, from then on those who are still alive do the devotional yajñas to their ancestors. Manawa Dharmasastra III. 275 there is stated that whatever is done by someone with full confidence will get satisfaction and happiness after he worshiped his ancestors in accordance with the rules. Likewise, in Manawa Dharmasastra III.203 it is stated for dwijati to worship ancestors first rather than worshiping Gods, because worshiping the ancestors will strengthen worship of Gods manifested by God Almighty. Devotion to ancestors is paramo dharmah, which is a noble obligation as a tangible manifestation of the practice of pitra yajña teachings in the form of pitra puja "tar malupeng pitra puja" as stated in Kakawin Ramayana, which means that we will not forget the worship of the ancestors. Because it was the ancestors who contributed to our existence in this world and as pratisentana or their descendants we are also obliged to continue to provide the best, for a decent place for the ancestors in the pitara world. The maligya ceremony in Cakranegara territory which is held until the nilapati ceremony serves as a means of increasing the sraddha (belief) and bhakti (devotion) of Hindus to their ancestors. Their ancestors deliver to melinggh (placed) at kemulanagar they can offer worship services, and where they ask for guidance and protection because they are considered to have been integrated with other dewa pitara (gods).

The practice of cultural values in the maligya ceremony that takes place in the middle of the life of the Hindu community in Cakranegara indirectly has educational significance. This is very apparent especially when making the facilities needed to support the success of the ceremony. From the beginning, the tukang banten (ritual means makers) was assisted by many people who wanted to know how to make jaja suci, including the required jejahitan-jejahitan at the time of offering. Serati or ritual means makers here is limited, so it needs help from the people to realize the success of the preparation for the Maligya ceremony. Not all people can do it perfectly, so the tukang banten here gives instructions to those who are ngayah about how to make, metanding including also regulating the necessary facilities. The activity and 
instructions given by the tukang bantento all the assistants who assisted him was an unconscious implementation of the educational process.

The leader of the ceremony in this maligya ceremony also gives directions and important instructions to the banten handlers and all the people who are in charge and responsible in the ceremony to do the things that are needed or carried out from the beginning to the end of the ceremony. This process is a form of education carried out by the ceremonial leader to the tuykang banten and all the people who help him. Likewise, when offering devotions, the leader of the ceremony gives instructions to all devotees, about the sequence of prayers, how many times to give devotional service, when to make merry, when to use flowers, when to use kuwangen, where to pray, when worship to the surya, to the ancestors, the nunas panugrahan, nunas wangsuh pada on, and mepamit. This is a form of ceremonial leader education process for all people involved at that time. The description above contains the content that in the implementation of the maligya ceremony contained didactic methods relating to the learning given to Hindus, especially among the younger generation concerning aspects of knowledge, skills, and attitudes that are built as a vehicle to improve the quality of self. The cultural values implemented in the maligya ceremony involve aspects of practicing the noble values passed down by the ancestors as an expression of devotion to the ancestors who have left this world.

\section{CONCLUSION}

Based on the description above it can be concluded three aspects related to this research. First, the practice of maligya ceremony contains the values of social education in the humanities, namely the introduction of cultural identity in religious practice as a cognitive aspect. In this regard, the maligya ceremony takes place in the process of introducing the noble values held by the Hindu community in Cakranegara which can be used as a vehicle to improve the quality of self, both individually and in groups. In the implementation of the maligya ceremony there is an indirect process of character building through concrete actions as evidenced in the form of devotion to the ancestors through the implementation of the ceremony. Self-introduction, especially related to the Balinese cultural identity imbued with the teachings of Hinduism can build a personal honest, disciplined, independent, and other attitudes that can improve the quality of self. Second, the implementation of the maligya ceremony contains educational values that involve living up to the noble values contained in each process of implementing the ceremony as an affective aspect. The appreciation of these values concerns aspects of taste that can build positive emotions in order to realize an improved quality of life. In this regard, the Hindu community that carries out the maligya ceremony can live the values contained in the ceremonial activities, especially those related to devotional values, both before the ancestors who have died and before the fellow human beings. Third, the practice of cultural values in the implementation of the maligya ceremony contains conative educational aspects. The conative dimension contained in the implementation of the maligya ceremony is indicated by the practice of the noble values contained in the ceremonial process from the beginning to the end of the ceremony. The practice of these values is actualized by the Hindu community in the form of performing sacrifices called yajña. This yajña is a form of devotional service which is actualized through the implementation of rituals from the initial planning of activities to the end of the ceremony. The values contained in the implementation of the maligya ceremony involve social, religious, and cultural aspects. These values are practiced as part of character education in creating a more dignified life.

\section{REFERENCES}

Arikunto, S. (2002). Metodologi Penelitian. Rineka Cipta.

Bungin, B. (2001). Metodelogi Penelitian Sosial, Format-Format Kuantitatif dan Kualitatif. Erlangga University Press.

Darmawan, I. P. A. (2020). Estetika Panca Suaradalam Upacara Yadnya di Bali. Jñānasiddhânta: Jurnal Teologi Hindu, 2(1), 61-70. http://jurnal.stahnmpukuturan.ac.id/index.php/jnanasidanta/article/view/821.

Emzir. (2011). Metodologi Penelitian Pendidikan. PT. Grafindo Persada.

Fuad, M., Efendi, A., \& Muhammad, U. A. (2020). The Use of Pepaccur Local Wisdom for Indonesian Literary Teaching Materials. Jurnal Pendidikan Indonesia, 9(2), 213-223. https: //doi.org/10.23887/jpi-undiksha.v9i2.22779.

Gentorang, I. M. A. (2016). Penggunaan Kajang dalam Ritus Kematian (Kelepasan) Klen Brahmana Buddha di Desa Budakeling dan Sebarannya di Desa Batuan. E-Jurnal Humanis, 15(3), 84-91. https://ojs.unud.ac.id/index.php/sastra/article/download/21861/14494. 
Miles, B., Huberman, M., \& Saldana, J. (2014). Qualitative Data Analysis: A Methods Sourcebook. SAGE Pub. Moleong, L. J. (2012). Metodologi Penelitian Kualitatif. Remaja Rosdakarya.

Muhajir, N. (1990). Metodologi Penelitian Kualitatif. Yake Sarasin.

Pitriani, N. R. V. (2020). Tattwa dalam Yadnya Perspektif Filsafat Hindu (Siwa Tattwa) bagi Masyarakat Hindu di Bali. ŚRUTI: Jurnal Agama Hindu, 1(1), 45-57. http://jurnal.ekadanta.org/index.php/sruti/article/view/61.

Purwita, I. B. P. (1997). Upacara Ngaben. Upada Sastra.

Putra. (1982). Kumpulan Kuliah-Kuliah Agama Hindu Jilid II. Cudamani.

Putra, N. (1988). Upacara Manusa Yadnya. IHD Denpasar.

Renawati, P. W. (2019). Implementasi Upacara Manusa Yadnya Dalam Naskah Dharma Kahuripan (Perspektif Teologi Hindu). Mudra Jurnal Seni Budaya, 34(3), 372-384. http://jurnal.isidps.ac.id/index.php/mudra/article/view/796.

Satori, A., \& Widiastuti, W. (2018). Model Pendidikan Multikultural pada Pesantren Tradisional di Kota Tasikmalaya dalam mencegah Ancaman Radikalisme. Sosiohumaniora, 20(1), 22-28. http://jurnal.unpad.ac.id/sosiohumaniora/article/view/10304.

Satori, Djam'an, \& Komariah, A. (2010). Metode Penelitian Kualitatif. Alfabeta.

Suamba, I. B. . (1996). Yajña Basis Kehidupan (Sebuah Canang Sari). Warta Hindu Dharma.

Sudarsana, I. B. P. (2002). Ajaran Agama Hindu Upacara Pitra Yajña. Yayasan Dharma Acarya Percetakan Mandara Sastra.

Sudarsana, I. K. (2017). Interpretation Meaning of Ngaben for Krama Dadia Arya Kubontubuh Tirtha Sari Ulakan Village Karangasem District (Hindu Religious Education Perspective). Vidyottama Sanatana: International Journal of Hindu Science and Religious Studies, 1(1), 1-13. http://www.ejournal.ihdn.ac.id/index.php/IJHSRS/article/view/148.

Sugiyono. (2012). Sugiyono. 2012. Metode Penelitian Kuantitatif, Kualitatif, dan R \& D. Bandung: Alfabeta. Suprayogo, I., \& Tabroni. (2001). Metode Penelitian Sosial-Agama. PT. Remaja Rosdakarya.

Suryawan, N., \& Gata, I. W. (2020). Catur Pariksa Sebagai Landasan Kepemimpinan Hindu Berbasis Kearifan Lokal (Suatu Tinjauan Pustaka). Suluh Pendidikan, 18(2), 225-235. http://jurnal.ikipsaraswati.ac.id/index.php/suluh-pendidikan/article/view/213.

Tantra, D. K. (2015). Solipsisme Bali: antara Persatuan dan Perseteruan. Wisnu Press.

Titib M. (2000). Theologi \& Simbol-Simbol dalam Agama Hindu. Paramita.

Wiana, I. K. (1998). Berbhakti Pada Leluhur Upacara Pitra Yajña dan Upacara Nuntun Dewa Hyang. Paramitha.

Wiana, I. K. (2004). Makna Upacara Yajña dalam Agama Hindu II. Paramitha.

Wiriawan, I. G. N. (2021). Upacara Manusa Yadnya Dalam Lontar Smarareka. Kalangwan Jurnal Pendidikan $\begin{array}{llll}\text { Agama, Bahasa Dan } & \text { Sastra, } & \text { 93-183. }\end{array}$ http://www.ejournal.ihdn.ac.id/index.php/Kalangwan/article/view/2362.

Yanti, N. L. P. Y. S. (2017). Upacara Ngaben Ningkeb Di Banjar Kebon Desa Pakraman Blahbatuh Kecamatan Blahbatuh Kabupaten Gianyar (Kajian Filosofis). Jurnal Penelitian Agama Hindu, 1(2), 472-478. http://www.ejournal.ihdn.ac.id/index.php/JPAH/article/view/284.

Zafi, A. A. (2018). Transformasi budaya melalui lembaga pendidikan (pembudayaan dalam pembentukan karakter). Al Ghazali, $1(1)$

$1-16$. https://ejournal.stainupwr.ac.id/index.php/al_ghzali/article/download/5/1. 